ISSN : 2338-4344

\title{
PENGARUH EKSTRAK AIR DAUN BABANDOTAN (Ageratum conyzoides) TERHAD AP PERTUMBUHAN TANAMAN CABAI MERAH (Capsicum annuUm L.)
}

\section{EFFECT OF AQUEOUS EXTRACTS OF WHITE WEED (Ageratum conyzoides) LEAVE ON THE GROWTH OF RED PEPPER PLANT (Capsicum annuum L.)}

\author{
Maria Reni Harnani ${ }^{1 *}$, Martha L. Lande ${ }^{1}$, Zulkifli ${ }^{1}$ \\ 1Jurusan Biologi FMIPA Universitas Lampung \\ *mariareniharnani@yahoo.co.id
}

\begin{abstract}
ABSTRAK
Babandotan (Ageratum conyzoides) mengandung senyawa alelopati yang mampu menghambat pertumbuhan tanaman. Tujuan penelitian ini untuk mengetahui apakah ekstrak air daun Ageratum conyzoides mempengaruhi pertumbuhan tanaman cabai merah (Capsicum annuum L.) Penelitian ini dilaksanakan bulan Juni sampai Juli 2016 di Laboratorium Fisiologi Tumbuhan, Jurusan Biologi, Universitas Lampung. Variabel dalam penelitian ini adalah tinggi, berat segar, berat kering, kadar air relatif, dan kandungan klorofil total tanaman cabai merah, sedangkan sebagai parameter adalah nilai tengah semua variabel. Penelitian dilakukan dalam rancangan acak lengkap dengan faktor utama adalah ekstrak air daun babandotan dengan 5 taraf konsentrasi yaitu $0 \% \mathrm{v} / \mathrm{v}$ (kontrol), $25 \% \mathrm{v} / \mathrm{v}, 50 \% \mathrm{v} / \mathrm{v}, 75 \% \mathrm{v} / \mathrm{v}, 100 \% \mathrm{v} / \mathrm{v}$. Analisis ragam dan uji BNT dilakukan pada taraf nyata $5 \%$. Hasil penelitian menunjukan bahwa ekstrak air daun babandotan menurunkan secara nyata tinggi tanaman $\left(y=-0.022 x+10.12 \quad R^{2}=0.706\right)$, berat segar tanaman $\left(y=-0.184 x+34.49 \quad R^{2}=0.932\right)$, berat kering tanaman $(y=-0.14 x+21.09$ $\left.R^{2}=0.819\right)$, namun meningkatkan kadar air relatif $\left(y=-0.136 x+39.26 \quad R^{2}=0.410\right)$. Tidak ada efek ekstrak air daun babandotan terhadap kandungan klorofil total. Dari hasil penelitian disimpulkan bahwa ekstrak air daun babandotan bersifat alelopati terhadap tanaman cabai merah yaitu menghambat pertumbuhan tanaman cabai merah.
\end{abstract}

Kata kunci : Capsicum annuum L., Ageratum conyzoides, faktor pertumbuhan

\begin{abstract}
White weed (Ageratum conyzoides) residues containing compounds capable of inhibiting the growth of plants. The purpose of this study to determine whether the water extract of leaves of white weed (Ageratum conyzoides) affect plant growth of red pepper (Capsicum annuum L.) This study was conducted from June to July 2016 in the Laboratory of Plant Physiology, Department of Biology, University of Lampung. The variable in this study was high, fresh weight, dry weight, relative water content, and total chlorophyll content of red pepper plant, while as a parameter is the mean of all the variables. The study was conducted in a completely randomized design with the main factor is the water extract of leaves of white weed with 5 concentration levels: $0 \% \mathrm{v} / \mathrm{v}$ (control), $25 \% \mathrm{v} / \mathrm{v}, 50 \% \mathrm{v} / \mathrm{v}, 75 \%$ $\mathrm{v} / \mathrm{v}, 100 \% \mathrm{v} / \mathrm{v}$. Analysis of variance and LSD test were performed at $5 \%$ significance level. The results showed that the water extract of leaves of white weed significantly decrease plant height $\left(y=-0.022 x 10: 12+R^{2}=0706\right)$, the fresh weight of the plants $(y=-0.184 x+$ $\left.34.49 R^{2}=0932\right)$, plant dry weight $\left(y=-21: 090.14 x+R^{2}=0819\right)$, but increases the relative water content $\left(y=-0.136 x+39.26 R^{2}=0.410\right)$. No effect of water extract of leaves of white weed on the total chlorophyll content. The final conclusion is that the water extract of leaves of white weed is allelophatic against red pepper plants that inhibit the growth of red pepper plants.
\end{abstract}

Keywords: Capsicum annuum L., Ageratum conyzoides, growth factors 


\section{PENDAHULUAN}

Cabai merah (Capsicum annuum L.) merupakan produk hortikultura penting yang banyak dibudidayakan oleh petani Indonesia. Keunggulan yang dimiliki oleh cabai merah yaitu bernilai ekonomis dan bermanfaat bagi kesehatan (Prajnanta, 2001).

Cabai merah termasuk tanaman semak tahunan dan tergolong ke dalam sayuran penting karena kebutuhan masyarakat semakin meningkat dalam penggunaan bahan penyedap dan pelengkap untuk menu masakan. Manfaat cabai merah terutama adalah sebagai penyedap berbagai masakan dan termasuk ke dalam sayuran multiguna yang memiliki peluang penting di dalam maupun luar negeri sehingga mempunyai nilai jual tinggi (Nawangsih et al., 1995).

Penyakit tanaman, hama, dan gulma mempengaruhi petumbuhan tanaman. Gulma merupakan organisme penganggu tanaman yang mampu menurunkan produktivitas tanaman (Sastroutomo, 1998). Salah satu peran gulma sebagai alelopati karena gulma mengeluarkan senyawa kimia yang dapat mempengaruhi pertumbuhan tanaman di sekitarnya.

Daun babandotan (Ageratum conyzoides) salah satu tanaman penggangu yang mengandung banyak volatile allelochemicals (ageratochromene dan derivatnya, monoterpene, sesquiterpene, dan flavon) saat kondisi stres. Senyawa alelokimia ini tidak hanya menghambat perkecambahan dan pertumbuhan tanaman yang berasosiasi tetapi juga akan mempengaruhi mikroba dan serangga (Idu dan Uvo-Oghale, 2013).

Senyawa volatil dan ekstrak air dari Ageratum conyzoides sudah diteliti memiliki efek alelopati pada beberapa kultivar tanaman budidaya (Okunade, 2001).

\section{BAHAN DAN METODE}

Penelitian ini telah dilakukan di Laboratorium Fisiologi Tumbuhan, Jurusan Biologi, Fakultas Matematika dan IImu Pengetahuan Alam, Universitas Lampung dari bulan Juni sampai Juli 2016.

Penelitian dilaksanakan dalam Rancangan Acak Lengkap dengan ekstrak daun babandotan sebagai faktor utama yang terdiri dari 5 taraf konsentrasi : $0 \% \mathrm{v} / \mathrm{v}$ (kontrol), 25 $\%$ v/v, $50 \%$ v/v, $75 \%$ v/v, dan $100 \%$ v/v. Setiap perlakuan diulang 5 kali perlakuan.

Variabel dalam penelitian ini adalah tinggi, berat kering, berat segar, kadar air relatif, dan kandungan klorofil cabai merah, dan sebagai parameter adalah nilai tengah $(\mu)$ adalah tinggi, berat kering, berat segar, kadar air relatif, dan kandungan klorofil cabai merah.

Larutan stok ekstrak air daun babandotan dibuat dengan menumbuk sampai halus 100 gram daun babandotan dan dilarutkan dalam $100 \mathrm{ml}$ aquades dan dibiarkan selama 24 jam. Ekstrak disaring dengan menggunakan kain kassa dan kertas saring Whatman no. 1 ke dalam erlenmeyer dan siap digunakan. 
Pemberian ekstrak air daun babandotan dilakukan pada saat tanaman cabai merah berumur 3 minggu, dan pengamatan dilakukan 1 minggu setelah perlakuan. Tinggi tanaman diukur mulai dari permukaan tanah sampai titik tumbuh tanaman cabai merah. Pengukuran dilakukan dengan penggaris dalam satuan sentimeter. Berat segar tanaman ditentukan dengan cara menimbang bahan tanaman dengan neraca digital dan dinyatakan dalam miligram. Berat kering tanaman ditentukan dengan neraca digital setelah bahan tanaman dikeringkan dalam oven pada temperatur 105$110^{\circ} \mathrm{C}$ selama 2 jam, dan dinyatakan dalam satuan miligram. Menurut Yamasaki dan Dillenburg (1999) kadar air relatif ditentukan dengan rumus:

Kadar air relatif $=\frac{M 1-M 2}{M 1} \times 100 \%$

Keterangan : $M_{1}=$ Berat segar tanaman $\mathrm{M}_{2}=$ Berat kering tanaman

Menurut Miazek (2002) kandungan klorofil ditentukan dengan cara sebanyak 0,1 gram daun tanaman cabai merah digerus sampai halus ke dalam mortar, lalu ditambahkan $10 \mathrm{ml}$ etanol 95\%. Ekstrak disaring ke dalam tabung reaksi dan diukur absorbansinya pada panjang gelombang $648 \mathrm{~nm}$ dan $664 \mathrm{~nm}$. Kandungan klorofil dinyatakan dalam milligram per gram jaringan dan dihitung berdasarkan persamaan berikut :
$\mathrm{Chl}_{\text {total }}=5.24 . \mathrm{A} 664+22.24 \mathrm{~A} .648\left(\frac{v}{w \times 1000}\right)$

\begin{tabular}{lll}
\multicolumn{2}{l}{ Keterangan } \\
Chl total & $:$ klorofil total \\
A664 & $:$ absorbansi pada panjang gelombang \\
& $648 \mathrm{~nm}$ \\
$\mathrm{~A} 648 \quad:$ & absorbansi pada panjang gelombang \\
& 664 \\
$\mathrm{~V}$ & $:$ & volume etanol \\
$\mathrm{W}$ & $:$ & berat daun
\end{tabular}

Homogenitas ragam diuji dengan uji Bartlett. Analisis ragam dan uji BNT dilakukan pada taraf nyata $5 \%$. Hubungan antara konsentrasi ekstrak daun babandotan dan variabel pertumbuhan ditentukan berdasarkan regresi linear.

\section{HASIL PEMBAHASAN}

Tinggi Tanaman

Berdasarkan uji BNT rata-rata tinggi tanaman cabai merah setelah perlakuan ekstrak air daun babandotan ditunjukan pada Tabel 1 . Analisis ragam pada taraf nyata $5 \%$ menunjukan bahwa pemberian ekstrak air daun babandotan berpengaruh nyata terhadap tinggi tanaman.

Uji BNT pada taraf nyata 5\% menunjukan bahwa rata-rata tinggi tanaman cabai merah perlakuan 50, 75, dan $100 \% \mathrm{v} / \mathrm{v}$ ekstrak air daun babandotan berbeda nyata dari rata-rata tinggi tanaman cabai merah kontrol. Tidak ada perbedaan yang nyata dalam rata-rata tinggi tanaman antara tanaman cabai merah kontrol dengan tanaman cabai merah perlakuan $25 \%$ v/v ekstrak air daun babandotan. Demikian juga tidak ada perbedaan yang nyata dalam rata-rata tinggi tanaman cabai merah 
perlakuan 50, 75, dan $100 \%$ v/v. Efek sensitivitas ekstrak air daun babandotan berpengaruh terhadap tinggi tanaman pada konsentrasi $50-100 \% \mathrm{v} / \mathrm{v}$ sehingga konsentrasi $50 \% \mathrm{v} / \mathrm{v}$ sudah mempengaruhi tinggi tanaman cabai merah.

Tabel 1. Uji BNT rata-rata tinggi tanaman cabai merah setelah pemberian ekstrak air daun babandotan

\begin{tabular}{cc}
\hline $\begin{array}{c}\text { Konsentrasi ekstrak air } \\
\text { daun babandotan } \\
(\% \text { v/v) }\end{array}$ & $\begin{array}{c}\text { Tinggi tanaman } \\
(\mathbf{c m})\end{array}$ \\
\hline 0 & $10.5 \pm 0.98^{\mathrm{a}}$ \\
25 & $9.7 \pm 0.59^{\mathrm{a}}$ \\
50 & $8.2 \pm 0.66^{\mathrm{b}}$ \\
75 & $8.1 \pm 0.57^{\mathrm{b}}$ \\
100 & $8.5 \pm 0.54^{\mathrm{b}}$ \\
\hline Keterangan : Angka yang diikuti dengan huruf \\
yang sama tidak berbeda nyata. \\
Tinggi tanaman $\mu=\overline{\mathrm{Y}} \pm \mathrm{t} \mathrm{\alpha} / 2 \mathrm{~S} \overline{\mathrm{Y}}$. BNT \\
0.05=1.03, $\mathrm{n}=5$
\end{tabular}

Tinggi tanaman cabai merah berkorelasi linear negatif dengan konsentrasi ekstrak air daun babandotan (Gambar 1). Rata-rata tinggi tanaman cabai merah menurun dengan meningkatnya konsentrasi ekstrak air daun babandotan. Rata-rata tinggi tanaman cabai merah menurun dengan meningkatnya konsentrasi ekstrak air daun babandotan. Regresi linear menghasilkan $R^{2}=0.706$ sehingga ekstrak air daun babandotan berpengaruh terhadap tinggi tanaman cabai merah sebanyak $70 \%$.

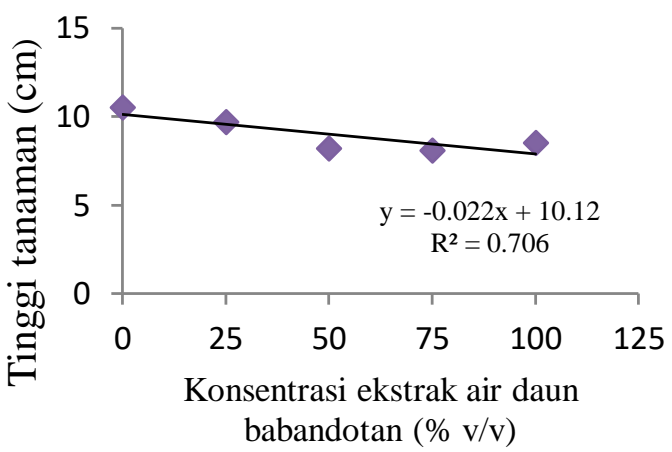

Gambar 1. Kurva korelasi antara tinggi tanaman cabai merah dengan ekstrak air daun babandotan

\section{Berat segar tanaman}

Berdasarkan uji BNT rata-rata berat segar tanaman cabai merah setelah perlakuan ekstrak air daun babandotan ditunjukan pada Tabel 2. Analisis ragam pada taraf nyata $5 \%$ menunjukan bahwa pemberian ekstrak air daun babandotan berpengaruh nyata terhadap berat segar tanaman.

Tabel 2. Uji BNT rata-rata berat segar tanaman cabai merah setelah pemberian ekstrak air daun babandotan

\footnotetext{
Konsentrasi ekstrak air daun babandotan Berat segar $(\% \mathrm{v} / \mathrm{v})$ tanaman (mg)

\begin{tabular}{cc}
$(\% \mathbf{v} / \mathbf{v})$ & tanaman $(\mathbf{m g})$ \\
\hline 0 & $35.26 \pm 3.70^{\mathrm{a}}$ \\
25 & $29.76 \pm 3.44^{\mathrm{b}}$ \\
50 & $23.84 \pm 1.77^{\mathrm{c}}$ \\
75 & $18.16 \pm 1.41^{\mathrm{d}}$ \\
100 & $18.42 \pm 1.15^{\mathrm{d}}$ \\
\hline
\end{tabular}

Keterangan : Angka yang diikuti dengan huruf yang sama tidak berbeda nyata. Berat segar tanaman $\mu=\bar{Y} \pm \mathrm{t} \alpha / 2 \mathrm{~S} \overline{\mathrm{Y}}, \mathrm{BNT} 0.05=3.80, \mathrm{n}=5$

Uji BNT pada taraf nyata 5\% menunjukan bahwa rata-rata berat segar tanaman cabai merah perlakuan $25,50,75$, dan $100 \% \mathrm{v} / \mathrm{v}$ ekstrak air daun babandotan berbeda nyata
} 
dari rata-rata berat segar tanaman cabai merah kontrol. Ada perbedaan yang nyata dalam rata-rata berat segar daun tanaman cabai merah kontrol dengan tanaman cabai merah perlakuan $25,50,75$, dan $100 \% \mathrm{v} / \mathrm{v}$. Demikian juga tidak ada perbedaan yang nyata dalam rata-rata berat segar tanaman cabai merah perlakuan 75 dan $100 \%$ v/v. Efek sensitivitas ekstrak air daun babandotan berpengaruh terhadap berat segar tanaman pada konsentrasi $25-100 \% \quad \mathrm{v} / \mathrm{v}$ sehingga konsentrasi $25 \% \mathrm{v} / \mathrm{v}$ sudah mempengaruhi berat segar tanaman cabai merah. Namun konsentrasi $75-100 \% \mathrm{v} / \mathrm{v}$ sangat rentan dan memberikan efek negatif terhadap berat segar tanaman.

Berat segar tanaman cabai merah berkorelasi linear negatif dengan konsentrasi ekstrak air daun babandotan (Gambar 2). Rata-rata berat segar tanaman cabai merah menurun dengan meningkatnya konsentrasi ekstrak air daun babandotan. Regresi linear menghasilkan $\mathrm{R}^{2}=0.932$ sehingga ekstrak air daun babandotan berpengaruh terhadap berat segar tanaman cabai merah sebanyak $90 \%$.

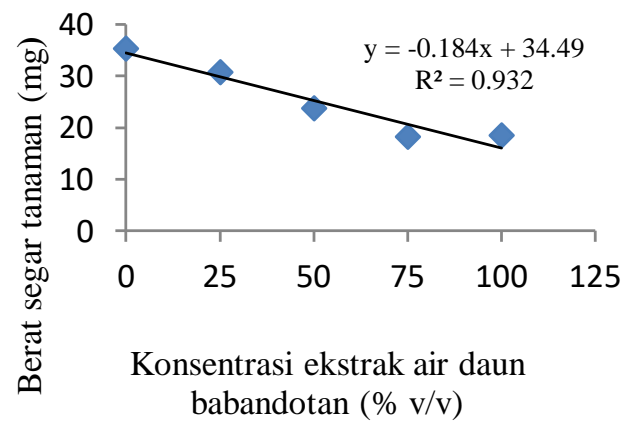

Gambar 2. Kurva korelasi antara berat segar tanaman cabai merah dengan ekstrak air daun babandotan

\section{Berat kering tanaman}

Berdasarkan uji BNT rata-rata berat kering tanaman cabai merah setelah perlakuan ekstrak air daun babandotan ditunjukan pada Tabel 3. Analisis ragam pada taraf nyata $5 \%$ menunjukan bahwa pemberian ekstrak air daun babandotan berpengaruh nyata terhadap berat kering tanaman cabai merah.

Tabel 3. Uji BNT rata-rata berat kering tanaman cabai merah setelah pemberian ekstrak air daun babandotan

\begin{tabular}{cc}
\hline $\begin{array}{c}\text { Konsentrasi ekstrak air } \\
\text { daun babandotan } \\
(\% \mathbf{v} / \mathbf{v})\end{array}$ & $\begin{array}{c}\text { Berat kering } \\
\text { tanaman }(\mathbf{m g})\end{array}$ \\
\hline 0 & $22.66 \pm 3.87^{\mathrm{a}}$ \\
55 & $18.10 \pm 1.58^{\mathrm{b}}$ \\
75 & $11.58 \pm 2.12^{\mathrm{c}}$ \\
100 & $7.82 \pm 3.52^{\mathrm{c}}$ \\
\hline Keterangan: Angka yang diikuti dengan huruf \\
yang sama tidak berbeda nyata. \\
Berat kering tanaman $\mu=\overline{\mathrm{Y}} \pm \mathrm{t} \alpha / 2$ \\
S̄ $\mathrm{\alpha NT} 0.05=4.08, \mathrm{n}=5$
\end{tabular}

Uji BNT pada taraf nyata $5 \%$ menunjukan bahwa rata-rata berat kering tanaman cabai merah perlakuan $25,50,75$, dan $100 \% \mathrm{v} / \mathrm{v}$ ekstrak air daun babandotan berbeda nyata dari rata-rata berat kering tanaman cabai merah kontrol. Ada perbedaan yang nyata dalam rata-rata berat kering antara tanaman cabai merah kontrol dengan tanaman cabai merah perlakuan $25,50,75$, dan $100 \% \mathrm{v} / \mathrm{v}$ ekstrak air daun babandotan. Demikian juga tidak ada perbedaan yang nyata dalam ratarata berat kering tanaman cabai merah perlakuan 50, 75, dan $100 \% \mathrm{v} / \mathrm{v}$ ekstrak air daun babandotan. Efek sensitivitas ekstrak air daun babandotan berpengaruh terhadap berat kering tanaman pada konsentrasi $25-100 \% \mathrm{v} / \mathrm{v}$ sehingga konsentrasi $25 \% \quad \mathrm{v} / \mathrm{v}$ sudah 
mempengaruhi berat kering tanaman cabai merah. Namun konsentrasi 50-100\% v/v sangat rentan dan memberikan efek negatif terhadap berat kering tanaman. Berat kering tanaman cabai merah berkorelasi linear negatif dengan konsentrasi ekstrak air daun babandotan (Gambar 3).

Rata-rata berat kering tanaman cabai merah menurun dengan meningkatnya konsentrasi ekstrak air daun babandotan. Regresi linear menghasilkan $R^{2}=0.819$ sehingga ekstrak air daun babandotan berpengaruh terhadap berat kering tanaman cabai merah sebanyak $80 \%$.

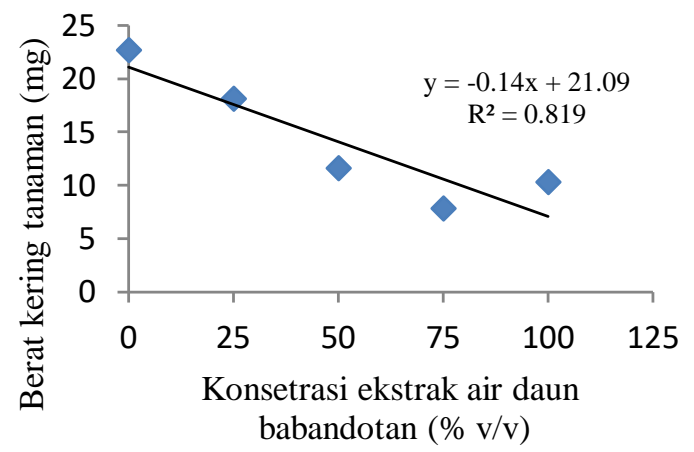

Gambar 3. Kurva korelasi antara berat kering tanaman cabai merah dengan ekstrak air daun babandotan

\section{Kadar air relatif}

Berdasarkan uji BNT rata-rata kadar air relatif setelah perlakuan ekstrak air daun babandotan ditunjukan pada Tabel 4. Analisis ragam pada taraf nyata $5 \%$ menunjukan bahwa pemberian ekstrak air daun babandotan meningkatkan kadar air relatif.

Uji BNT pada taraf nyata 5\% rata-rata kadar air relatif perlakuan 50, 75 dan 100\% v/v ekstrak air daun babandotan tidak berbeda nyata dari rata-rata kadar air relatif kontrol. Tidak ada perbedaan yang nyata dalam rata-rata kadar air relatif tanaman cabai merah kontrol dengan rata-rata kadar air relatif perlakuan 25,50 , dan $100 \% \mathrm{v} / \mathrm{v}$ ekstrak air daun babandotan. Demikian juga tidak ada perbedaan yang nyata rata-rata kadar air relatif perlakuan 50,75 , dan $100 \%$ v/v. Efek sensitivitas ekstrak air daun babandotan berpengaruh terhadap kadar air relatif pada konsentrasi $75 \% \mathrm{v} / \mathrm{v}$ sehingga konsentrasi $75 \% \mathrm{v} / \mathrm{v}$ sudah mempengaruhi kadar air relatif tanaman cabai merah.

Tabel 4. Uji BNT rata-rata kadar air relatif setelah pemberian ekstrak air daun babandotan

\begin{tabular}{cc}
\hline $\begin{array}{c}\text { Konsentrasi ekstrak air } \\
\text { daun babandotan }(\% \\
\text { v/v) }\end{array}$ & $\begin{array}{c}\text { Kadar air relatif } \\
(\%)\end{array}$ \\
\hline 0 & $37.50 \pm 8.47^{\mathrm{a}}$ \\
25 & $38.98 \pm 4.70^{\mathrm{a}}$ \\
50 & $51.12 \pm 6.08^{\mathrm{ab}}$ \\
75 & $57.65 \pm 17.08^{\mathrm{b}}$ \\
100 & $45.24 \pm 7.37^{\mathrm{ab}}$ \\
\hline Keterangan: Angka yang diikuti dengan huruf \\
\multicolumn{2}{c}{ yang sama tidak berbeda nyata. } \\
Kadar air relatif $\mu=\overline{\mathrm{Y}} \pm \mathrm{t} \mathrm{\alpha} / 2 \mathrm{~S} \overline{\mathrm{Y}}, \mathrm{BNT}$ \\
\multicolumn{2}{c}{$0.05=14.70, \mathrm{n}=5$}
\end{tabular}

Kadar air relatif berkorelasi linear positif dengan konsentrasi ekstrak air daun babandotan (Gambar 4). Rata-rata kadar air relatif meningkat dengan meningkatnya konsentrasi ekstrak air daun babandotan. Regresi linear menghasilkan $R^{2}=0.410$ sehingga ekstrak air daun babandotan berpengaruh terhadap kadar air relatif tanaman cabai merah sebanyak $40 \%$. 


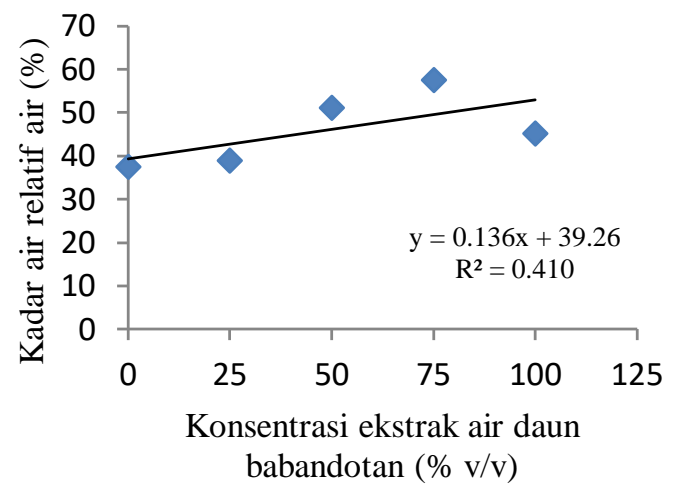

Gambar 4. Kurva korelasi antara kadar air relatif dengan ekstrak air daun babandotan

\section{Kandungan klorofil total}

Berdasarkan rata-rata kandungan klorofil total setelah perlakuan ekstrak air daun babandotan ditunjukan pada (Gambar 5). Analisis ragam pada taraf nyata $5 \%$ menunjukan bahwa tidak ada perbedaan yang nyata terhadap kandungan klorofil total.

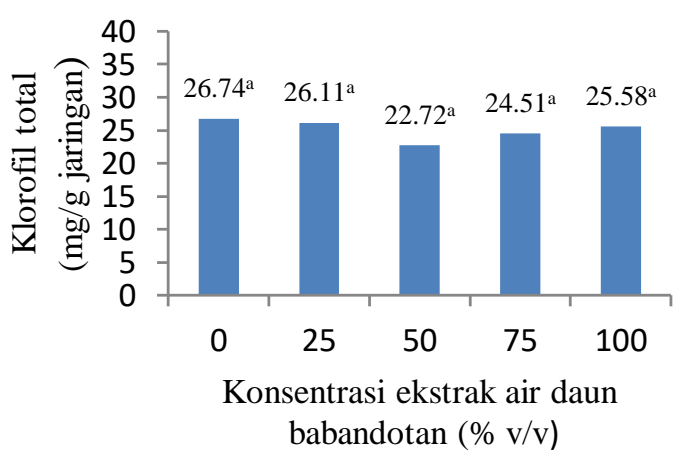

Gambar 5. Diagram kandungan klorofil total dengan ekstrak air daun babandotan

Efek ekstrak air daun babandotan terhadap pertumbuhan tanaman cabai merah ditunjukan pada Tabel 6.
Tabel 6. Efek ekstrak air daun babandotan terhadap pertumbuhan tanaman cabai merah

\begin{tabular}{|c|c|c|c|}
\hline Variabel & Efek & $\begin{array}{c}\text { Konsentrasi } \\
(\% \mathrm{v} / \mathrm{v})\end{array}$ & $\begin{array}{c}\text { Besarnya } \\
\text { Perubahan } \\
(\%)\end{array}$ \\
\hline Tinggi & & 50 & 21.9 \\
\hline $\begin{array}{l}\text { Berat } \\
\text { segar }\end{array}$ & & $25-75$ & $12.9-48.5$ \\
\hline $\begin{array}{l}\text { Berat } \\
\text { kering }\end{array}$ & & $25-50$ & $20.1-48.9$ \\
\hline $\begin{array}{l}\text { Kadar air } \\
\text { relatif }\end{array}$ & & 75 & 53.7 \\
\hline $\begin{array}{l}\text { Klorofil } \\
\text { total }\end{array}$ & - & - & - \\
\hline
\end{tabular}

Hasil penelitian menunjukan bahwa ekstrak air daun babandotan berefek negatif terhadap tinggi, berat segar, dan berat kering tanaman cabai merah. Konsentrasi ekstrak air daun babandotan $50 \% \quad \mathrm{v} / \mathrm{v}$ efektif menurunkan variabel pertumbuhan tinggi tanaman dengan besar perubahan $21.9 \%$. Peningkatan konsentrasi selanjutnya (75 sampai $100 \% \mathrm{v} / \mathrm{v}$ ) hanya sedikit menurunkan tinggi tanaman cabai merah atau tidak berdampak nyata terhadap tinggi tanaman cabai merah (Tabel $1)$.

Demikian juga konsentrasi $25-75 \%$ v/v ekstrak air daun babandotan efektif menurunkan berat segar dengan besar perubahan 12.9-48.5\%. Peningkatan konsentrasi selanjutnya (75 sampai $100 \% \mathrm{v} / \mathrm{v}$ ) berdampak signifikan terhadap penurunan berat segar tanaman cabai merah (Tabel 2). Sedangkan konsentrasi 25-50 \% v/v efektif menurunkan berat kering dengan besar perubahan 20.148.9\%. Peningkatan konsentrasi selanjutnya (50 sampai $100 \% \mathrm{v} / \mathrm{v}$ ) berdampak signifikan 
terhadap penurunan berat kering tanaman cabai merah (Tabel 3).

Sebaliknya, ekstrak air daun babandotan berefek positif terhadap kadar air relatif tanaman cabai merah. Konsentrasi $75 \% \mathrm{v} / \mathrm{v}$ efektif meningkatkan kadar air relatif tanaman cabai merah yaitu sebesar $53.7 \%$ (Tabel 4). Ekstrak air daun babandotan tidak berefek terhadap kandungan klorofil total (Gambar 5).

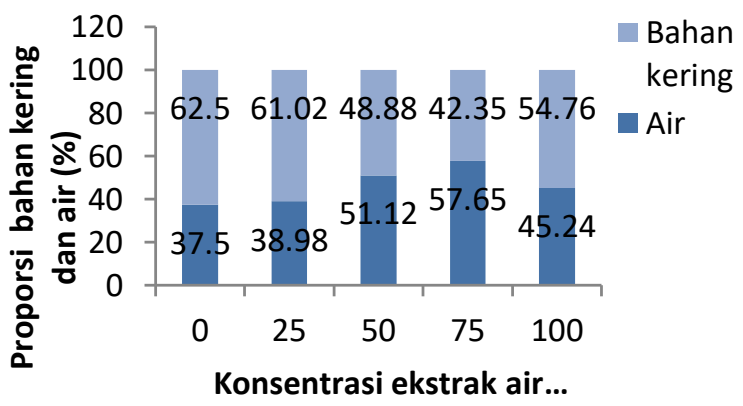

Gambar 6. Proporsi bahan kering dan air tanaman cabai merah

Analisis proporsi bahan kering dan air bahwa ekstrak air daun babandotan mengubah proporsi bahan kering dan air dengan meningkatkan proporsi air. Oleh sebab itu efek positif ekstrak air daun babandotan terhadap pertumbuhan tanaman cabai merah adalah meningkatkan penyerapan air.

Hasil penelitian ini mendukung laporan Kong (2006) bahwa babandotan mengandung senyawa alelokimia yang mampu menghambat pertumbuhan tanaman dengan cara memproduksi melepaskan senyawa volatil ke lingkungan.

Senyawa-senyawa fenol yang dilepaskan ke dalam tanah oleh tanaman akan menghambat aktivitas hormon auksin dan berperan penting dalam aktivasi enzim IAA oksidase yang mengkatalisis oksidasi auksin menjadi senyawa tidak aktif (Sastroutomo, 1990).

Hormon IAA tidak menghambat imbibisi pada tanaman cabai merah sehingga kadar air relatif meningkat. Secara visualisasi penghambatan hormon IAA terhadap imbibisi yaitu tanaman berwarna hijau. Gangguan aktivitas hormon tumbuhan IAA yang berperan dalam pertumbuhan tanaman dapat dipicu oleh senyawa alelopati ekstrak daun babandotan (Wattimena, 1987).

Senyawa saponin, flavonoid, polifenol, dan HCN mampu menghambat pembelahan sel sehingga menghambat pertumbuhan tanaman (Togatorop, 2008).

Hasil penelitian ekstrak air daun babandotan mengandung senyawa-senyawa alelokimia sehingga mampu menghambat pertumbuhan tinggi dan biomassa tanaman cabai merah.

\section{KESIMPULAN}

Ekstrak air daun babandotan mempengaruhi pertumbuhan tanaman cabai merah dengan berbagai konsentrasi.

\section{SARAN}

Perlu dilakukan penelitian pengaruh ekstrak air daun babandotan terhadap pertumbuhan tanaman lainnya. 


\section{DAFTAR PUSTAKA}

Idu, M., dan Uvo-Oghale, O. 2013. Studies on The Allelophatic Effect of Aqueous Extract of Ageratum Conyzoides Asteraceae on Seedling Growth of Sesasum indicum L. (Pedaliaceae). J. Scitec. Vol. 2, 1185-1195.

Kong, C. 2006. Allelochemicals from Ageratum conyzoides $\mathrm{L}$. and Oriza sativa L. and Their Effects on Related Pathogens. 194-195.

Miazek, K. 2002. Chlorophyll Extraction From Harvested Plant Material. Supervisor : Prof. dr. hab inz Stanislaw Ledakowics.

Nawangsih, A.A, Imadad, H.P, Wahyudi, A. 1995. Cabai Hot Beauty. PT. Penebar Swadaya. Bogor.

Okunade, A.L. 2001. Ageratum conyzoides (Asteraceae). Fitoterapia. 73: 1-16.
Prajnanta, F. 2001. Agribisnis Cabai Hibrida. PT. Penebar Swadaya. Bogor.

Sastroutomo, S. 1990. Ekologi Gulma. PT Gramedia Pustaka Utama. Jakarta.

Sastroutomo, S. 1998. Ekologi Gulma. PT Gramedia Pustaka Utama. Jakarta.

Togatorop, D.A. 2009. Studi Alelopati Wedelia tribobata, Ageratum conyzoides, Chromolaena odorata, dan Mikania micrantha Terhadap Pertumbuhan dan Hasil Sawi. J. Floratek. 18-24

Wattimena, G.A. 1987. Zat Pengantur Tumbuh. PAU Bioteknologi IPB. Bogor.

Yamasaki, S dan Dillenburg, L.R. 1999. Measurement Of Leaf Relative Water Content In Araucaria Angustifolia Revista Brarileira de Fisiologia Fegetal, 11(2). 69-75 
---This page left blank--- 